\title{
Understanding Patients with Type 2 Diabetes Mellitus Using Oral Antidiabetic Drugs
}

Gambaran Penderita Diabetes Mellitus tipe 2 dengan Obat Antidiabetik Oral

\author{
Grace Y Irene *, Kuswinarti**, Maya Kusumawati*** \\ *Faculty of Medicine Padjadjaran University \\ **Department of Pharmacology and Therapy Faculty of Medicine Padjadjaran \\ University \\ ***Department of Internal Medicine Faculty of Medicine Padjadjaran University \\ -Hasan Sadikin General Hospital \\ Jl. Prof. Eyckman No. 38 Bandung 40161 Indonesia \\ Email: graceyumeko97@gmail.com
}

Received: November 21, 2018

Accepted: February 24, 2020

\begin{abstract}
Uncontrolled hyperglycemia in people with diabetes mellitus can increase the risk of diabetes complications and comorbidities. This study aimed to determine the demographic, clinical, history, complications, and comorbid characteristics of diabetes. The study was conducted with a descriptive method and cross-sectional research design. Data were collected retrospectively using medical record data and using the Finite Population Correction formula with a sample of 115. The results showed the majority of patients were female (67.8\%), aged $\geq 65$ years $(40.0 \%)$, residing in urban (87.6\%), high school graduates (35.2\%), and unemployed (63.6\%). Patients generally have a normal BMI (45.9\%) and have several variables that reach the target, namely fasting blood glucose (50.4\%), triglycerides (55.3\%), and creatinine (69.6\%). Patients also had several variables that did not reach the target, namely postprandial 2 hour blood glucose (51.3\%), blood pressure (65.8\%), total cholesterol (55.6\%), HDL cholesterol (54.5\%), LDL cholesterol (80.0\%), and urea (56.0\%). Patients who use oral anti-diabetes generally have used it $<5$ years (76.3\%) and used monotherapy (63.5\%). Neuropathy (42.6\%) and hypertension (85.9\%) were the most common complications and comorbidities of diabetes in this study. Strict glycemic control is an important management for people with diabetes mellitus.
\end{abstract}

Keywords: oral antidiabetic drugs; diabetes mellitus; comorbid

\begin{abstract}
Abstrak
Hiperglikemia yang tidak terkontrol pada penderita diabetes mellitus dapat meningkatkan resiko terjadinya komplikasi dan komorbid diabetes. Penelitian ini bertujuan untuk mengetahui karakteristik demografi, klinis, riwayat, komplikasi, dan komorbid diabetes. Penelitian dilakukan dengan metode deskriptif dan desain penelitian potong lintang. Pengambilan data dilakukan secara retrospektif dengan menggunakan data rekam medis dan menggunakan rumus Finite Population Correction dengan sampel berjumlah 115. Hasil penelitian menunjukkan mayoritas pasien berjenis kelamin perempuan $(67,8 \%)$, berusia $\geq 65$ tahun $(40,0 \%)$, bertempat tinggal di perkotaan $(87,6 \%)$, lulusan SMA $(35,2 \%)$, dan tidak bekerja $(63,6 \%)$. Pasien umumnya memiliki IMT normal $(45,9 \%)$ dan memiliki beberapa variabel yang mencapai target, yaitu glukosa darah puasa $(50,4 \%)$, trigliserida $(55,3 \%)$, dan kreatinin $(69,6 \%)$. Pasien juga memiliki beberapa variabel yang tidak mencapai target, yaitu glukosa darah 2 jam postprandial (51,3\%), tekanan
\end{abstract}


darah (65,8\%), kolesterol total (55,6\%), kolesterol HDL (54,5\%), kolesterol LDL (80,0\%), dan ureum $(56,0 \%)$. Pasien yang menggunakan antidiabetes oral umumnya telah menggunakannya < 5 tahun $(76,3 \%)$ dan menggunakan monoterapi $(63,5 \%)$. Neuropati $(42,6 \%)$ dan hipertensi $(85,9 \%)$ adalah komplikasi dan komorbid diabetes tersering pada penelitian ini. Kontrol glikemik yang ketat merupakan manajemen penting bagi penderita diabetes melitus.

Kata Kunci: obat antidiabetes oral; diabetes mellitus; komorbid

\section{Pendahuluan}

Diabetes melitus adalah kumpulan gejala yang disebabkan oleh gangguan metabolik dengan karakteristik hiperglikemia akibat kekurangan insulin baik secara absolut maupun relatif. ${ }^{1}$ Perkumpulan Endokrinologi Indonesia (PERKENI) 2015 mengklasifikasikan diabetes melitus bedasarkan etiologinya menjadi 4 tipe, yaitu diabetes melitus tipe 1 , tipe 2 , tipe lain, dan gestasional. ${ }^{2}$ Diabetes merupakan satu dari empat penyakit tidak menular utama yang mempengaruhi masalah kesehatan secara global. ${ }^{3}$

Bentuk diabetes dengan prevalensi tertinggi adalah diabetes tipe 2 dengan angka $91 \%$ terjadi pada usia dewasa. ${ }^{4}$ Berdasarkan World Health Organization (WHO) tahun 2012, sebanyak 1,5 juta jiwa meninggal dunia akibat diabetes. ${ }^{3}$ Berdasarkan epidemiologi, diabetes melitus umumnya terjadi di wilayah Asia Pasifik. Hal tersebut disebabkan karena negara pertama, kedua, dan keempat dengan populasi terbanyak di dunia berada di kawasan Asia Pasifik, yaitu China, India, dan Indonesia. Data International Diabetes Federation (IDF) tahun 2017 menemukan bahwa jumlah penderita diabetes di Indonesia mencapai 10,3 juta jiwa dan menyebabkan Indonesia menempati peringkat ke-6 dengan jumlah penderita diabetes dewasa tertinggi di dunia. ${ }^{5}$

Angka total penderita diabetes diprediksi akan terus mengalami peningkatan dan diproyeksi akan mencapai 16,7 juta jiwa pada tahun 2045. WHO memprediksikan bahwa pada tahun 2025 akan terjadi peningkatan prevalensi diabetes, yaitu menjadi 300 juta jiwa, dan 150 juta jiwanya berasal dari wilayah Asia Pasifik. ${ }^{5}$ Laporan hasil Riset Kesehatan Dasar (RISKESDAS) 2018 menunjukkan bahwa terjadi peningkatan prevalensi diabetes di Indonesia, dengan proporsi penduduk usia $\geq 15$ tahun adalah 8,5\%. Data RISKESDAS 2018 menunjukkan bahwa penderita diabetes melitus di Jawa Barat mencapai 1,8\%. Prevalensi DM cenderung lebih tinggi pada perempuan $(1,8 \%)$ dari pada laki-laki $(1,2 \%)$, di perkotaan $(1,9 \%)$ dari pada pedesaan $(1,0 \%)$, dan lebih tinggi pada masyarakat dengan tingkat pendidikan tinggi $(2,8 \%)$ dengan kuintil indeks kepemilikan tinggi. Gejala diabetes akan meningkat sesuai dengan bertambahnya usia. ${ }^{6}$

Faktor risiko yang dapat menyebabkan terjadinya diabetes ialah kombinasi antara genetik, perubahan gaya hidup yang dipengaruhi oleh pola makan dan aktivitas fisik, westernisasi (kebarat-baratan), urbanisasi (perubahan sifat suatu tempat dari suasana desa ke suasana kota), 
dan mekanisasi (penggantian dan penggunaan tenaga mesin dan sarana-sarana teknik lainnya untuk menggantikan tenaga manusia dan hewan)..$^{5}$ Diabetes dapat berdampak pada bidang perekonomian dan sosial suatu negara. Dampak yang dihasilkan diantaranya terdapat peningkatan jumlah absen kerja, pengunduran diri dini, disabilitas, mortalitas, penurunan produktivitas kerja baik di kantor maupun rumah, dan dapat menyebabkan menurunnya gaji pegawai karena jumlah absen kerja yang melebihi jatah. ${ }^{7}$ Dalam bidang kesehatan, diabetes termasuk penyebab utama terjadinya peningkatan total pengeluaran. ${ }^{8}$

Komplikasi yang dapat terjadi pada penderita diabetes dapat bersifat akut maupun kronik. Komplikasi akut diantaranya adalah hiperglikemia dengan ketoasidosis atau hiperosmolar non ketogenik. Komplikasi kronik diantaranya dapat menyebabkan kerusakan pada beberapa organ, yaitu mata (retinopati), Diabetic Kidney Disease (DKD), syaraf (neuropati), pembuluh darah (aterosklerosis), dan jantung. ${ }^{9}$ Tujuan penelitian ini adalah untuk mengetahui karakteristik demografi, karakteristik klinis, riwayat diabetes, komplikasi dan komorbid diabetes pada pasien diabetes melitus tipe 2 yang menggunakan antidiabetes oral di Bagian Penyakit Dalam RSUD Kota Bandung pada Januari - Desember 2017.

\section{Metode}

Penelitian dilakukan dengan metode deskriptif dan desain penelitian potong lintang. Pengambilan data dilakukan secara retrospektif dengan menggunakan data sekunder, yaitu data rekam medis pasien diabetes melitus tipe 2 yang menggunakan antidiabetes oral di bagian Penyakit Dalam RSUD Kota Bandung pada periode Januari - Desember 2017. Persiapan penelitian dilakukan sejak bulan November 2017-Januari 2018 dan pengambilan serta pengolahan data dilakukan pada bulan Juni-September 2018.

Penelitian ini telah mendapat persetujuan etik dari Komite Etik Penelitian Universitas Padjadjaran Bandung dengan nomor 232/UN6.KEP/EC/2018, Badan Kesatuan Bangsa dan Politik Kota Bandung dengan nomor 070/697/Bakesbangpol, dan RSUD Kota Bandung dengan nomor 070/3539-RSUD/18. Kriteria inklusi pada penelitian ini adalah pasien diabetes melitus tipe 2 yang menggunakan antidiabetes oral dan datang berobat ke bagian penyakit dalam RSUD Kota Bandung pada periode Januari - Desember 2017. Kriteria eksklusi pada penelitian ini adalah pasien diabetes melitus tipe 2 yang menggunakan kombinasi antidiabetes oral dengan insulin dan data rekam medis yang tidak mencatat obat antidiabetes oral yang digunakan, kadar glukosa darah puasa, dan kadar glukosa 2 jam post prandial (2hPP). Pengambilan sampel dilakukan dengan metode Finite Population Correction dengan sampel berjumlah 115. 


\section{Research Article}

Data karakteristik demografi yang dinilai adalah jenis kelamin, umur, tempat tinggal, pendidikan, dan pekerjaan. Data karakteristik klinis yang dinilai adalah indeks massa tubuh, glukosa darah puasa, glukosa darah 2hPP, tekanan darah, kolesterol total, kolesterol HDL, kolesterol LDL, trigliserida, kreatinin, dan ureum. Data riwayat diabetes terdiri atas durasi penyakit dan jumlah obat antidiabetes yang digunakan. Data komplikasi dan komorbid diabetes yang dinilai yaitu komplikasi kronik dan komorbid yang paling banyak terjadi berdasarkan data International Diabetes Federation. Data dianalisis dengan menggunakan piranti lunak komputer, yaitu Microsoft Excel dan disajikan dalam bentuk tabel.

\section{Hasil}

Data diperoleh berdasarkan kriteria inklusi dan eksklusi. Metode pengambilan sampel menggunakan rumus Finite Population Correction dan didapatkan sebanyak 115 data rekam medis pasien diabetes melitus tipe 2 yang menggunakan obat antidiabetes oral di bagian Penyakit Dalam RSUD Kota Bandung Tahun 2017.

Penderita diabetes (diabetisi) yang menggunakan antidiabetes oral lebih banyak yang berjenis-kelamin perempuan $(67,8 \%)$, berada pada kelompok usia $\geq 65$ tahun $(40,0 \%)$, bertempat tinggal di wilayah Kotamadya (87,6\%), tamatan SMA (35,2\%), dan diabetesi tidak bekerja $(63,6 \%)$. Data dapat dilihat pada tabel 1 . 
Tabel 1 Karakteristik Demografi Pasien Diabetes Melitus Tipe 2 yang Menggunakan Antidiabetes Oral di Bagian Penyakit Dalam RSUD Kota Bandung Tahun $2017^{6}$

\begin{tabular}{lll}
\hline Karakteristik & $\mathrm{n}(\%$ per kategori) & $\mathrm{n}(\%$ per jumlah $)$ \\
\hline Jenis Kelamin & $37(32,2)$ & $115(100,0)$ \\
Laki-laki & $78(67,8)$ & \\
Perempuan & & $115(100,0)$ \\
Umur & $0(0,0)$ & \\
$15-24$ Tahun & $0(0,0)$ & \\
$25-34$ Tahun & $5(4,3)$ & \\
$35-44$ Tahun & $20(17,4)$ & \\
$45-54$ Tahun & $44(38,3)$ & \\
$55-64$ Tahun & $46(40,0)$ & \\
$\geq 65$ Tahun & & \\
Tempat tinggal & $99(87,6)$ & \\
Kotamadya & $14(12,4)$ & \\
Kabupaten & & \\
Pendidikan & $27(29,7)$ & \\
Tamat SD & $16(17,6)$ & \\
Tamat SMP & $32(35,2)$ & \\
Tamat SMA & $16(17,6)$ & \\
Tamat D1-D3/PT & & \\
Pekerjaan & $68(63,6)$ & \\
Tidak bekerja & $15(14,0)$ & \\
Pegawai & $6(5,6)$ & \\
Wiraswasta & $17(0,9)$ & \\
Petani/nelayan/buruh & & \\
Lainnya & &
\end{tabular}

Diabetisi yang menggunakan antidiabetes oral lebih banyak pada penderita dengan Indeks Massa Tubuh (IMT) normal (45,9\%). Target kendali HbA1C pada diabetisi hanya tercatat 2 dari 115 data rekam medis yang ada. Target kendali glukosa darah puasa pada diabetesi sebanyak 58 orang mencapai target $(50,4 \%)$ dan 57 orang tidak mencapai target $(49,6 \%)$, sedangkan target kendali glukosa darah 2 hPP sebanyak 59 orang tidak mencapai target $(51,3 \%)$ dan 56 orang mencapai target $(48,7 \%)$. Mayoritas tekanan darah pada diabetesi tidak mencapai target $(65,8 \%)$. Target kendali kolesterol pada diabetisi sebanyak 55,6\% tidak mencapai target normal kolesterol total, 54,5\% tidak mencapai target normal kolesterol HDL, dan sebanyak 80,0\% tidak mencapai target normal kolesterol LDL. Pada pemeriksaan trigliserida, sebanyak 55,3\% diabetisi tidak mencapai target normal trigliserida. Pada pemeriksaan kreatinin, kadar kreatinin pada perempuan dan laki-laki mecapai target, dengan persentase masing-masing 50,6\% dan $19,0 \%$. Pada pemeriksaan ureum, sebanyak 56,0\% diabetisi tidak mencapai target normal ureum. Data dapat dilihat pada tabel 2. 
Tabel 2 Karakteristik Klinis Pasien Diabetes Melitus Tipe 2 yang Menggunakan Antidiabetes Oral di Bagian Penyakit Dalam RSUD Kota Bandung Tahun 2017

\begin{tabular}{|c|c|c|}
\hline Karakteristik & n (\% per kategori) & n (\% per total) \\
\hline Indeks Massa Tubuh $\left(\mathrm{kg} / \mathrm{m}^{2}\right)$ & & $37(32,1)$ \\
\hline Berat badan kurang $\left(<18,5 \mathrm{~kg} / \mathrm{m}^{2}\right)$ & $1(2,7)$ & \\
\hline Berat badan normal $\left(18,5-22,9 \mathrm{~kg} / \mathrm{m}^{2}\right)$ & $17(45,9)$ & \\
\hline Beresiko $\left(23,0-24,9 \mathrm{~kg} / \mathrm{m}^{2}\right)$ & $13(35,1)$ & \\
\hline Obesitas I $\left(25,0-29,9 \mathrm{~kg} / \mathrm{m}^{2}\right)$ & $6(16,2)$ & \\
\hline Obesitas II $\left(\geq 30 \mathrm{~kg} / \mathrm{m}^{2}\right)$ & $0(0,0)$ & \\
\hline HbA1C (\%) & & $2(1,7)$ \\
\hline Good $(<7 \%)$ & $2(100,0)$ & \\
\hline Acceptable $(7-9 \%)$ & $0(0,0)$ & \\
\hline Poor $(>9 \%)$ & $0(0,0)$ & \\
\hline Glukosa Darah Puasa (mg/dl) & & $115(100,0)$ \\
\hline Target $(70-130 \mathrm{mg} / \mathrm{dl})$ & $58(50,4)$ & \\
\hline Non target $(>130 \mathrm{mg} / \mathrm{dl})$ & $57(49,6)$ & \\
\hline Glukosa Darah 2 jam post prandial $(\mathrm{mg} / \mathrm{dl})$ & & $115(100,0)$ \\
\hline Target $(<180 \mathrm{mg} / \mathrm{dl})$ & $56(48,7)$ & \\
\hline Non Target $(\geq 180 \mathrm{mg} / \mathrm{dL})$ & $59(51,3)$ & \\
\hline Tekanan Darah (mmHg) & & $114(99,1)$ \\
\hline Target $(\leq 130 / 80 \mathrm{mmHg})$ & $39(34,2)$ & \\
\hline Non Target $(>130 / 80 \mathrm{mmHg})$ & $75(65,8)$ & \\
\hline Kolesterol total (mg/dl) & & $36(31,3)$ \\
\hline Target $(<200 \mathrm{mg} / \mathrm{dl})$ & $16(44,4)$ & \\
\hline Non Target $(\geq 200 \mathrm{mg} / \mathrm{dl})$ & $20(55,6)$ & \\
\hline Kolesterol HDL (mg/dl) & & $11(9,6)$ \\
\hline Target $(>40 \mathrm{mg} / \mathrm{dl})$ & $5(45,5)$ & \\
\hline Non Target $(\leq 40 \mathrm{mg} / \mathrm{dl})$ & $6(54,5)$ & \\
\hline Kolesterol LDL (mg/dl) & & $55(47,8)$ \\
\hline Target $(<100 \mathrm{mg} / \mathrm{dl})$ & $11(20,0)$ & \\
\hline Non Target $(\geq 100 \mathrm{mg} / \mathrm{dl})$ & $44(80,0)$ & \\
\hline Trigliserida (mg/dl) & & $47(4,1)$ \\
\hline Target $(<150 \mathrm{mg} / \mathrm{dl})$ & $26(55,3)$ & \\
\hline Non Target $(\geq 150 \mathrm{mg} / \mathrm{dl})$ & $21(44,7)$ & \\
\hline Kreatinin (mg/dl) & & $79(68,7)$ \\
\hline Laki-laki & & \\
\hline Target $(0,8-1,4 \mathrm{mg} / \mathrm{dl})$ & $15(19,0)$ & \\
\hline Non Target (> 1,4 mg/dl) & $8(10,1)$ & \\
\hline Perempuan & & \\
\hline Target $(0,6-1,2 \mathrm{mg} / \mathrm{dl})$ & $40(50,6)$ & \\
\hline Non Target $(>1,2 \mathrm{mg} / \mathrm{dl})$ & $16(20,3)$ & \\
\hline Ureum (mg/dl) & & $25(21,7)$ \\
\hline Target $(7-20 \mathrm{mg} / \mathrm{dl})$ & $11(44,0)$ & \\
\hline Non Target $(\geq 20 \mathrm{mg} / \mathrm{dl})$ & $14(56,0)$ & \\
\hline
\end{tabular}


Tabel 3 Riwayat Pasien Diabetes Melitus Tipe 2 yang Menggunakan Obat Antidiabetes Oral di Bagian Penyakit Dalam RSUD Kota Bandung Tahun 2017

\begin{tabular}{lll}
\hline Karakteristik & n (\% per kategori) & n $(\%$ per total) \\
\hline Durasi Penyakit & & $115(100,0)$ \\
$\quad$ Durasi pendek ( $<5$ tahun) & $88(76,5)$ & \\
Durasi sedang $(6-10$ tahun) & $23(20,0)$ & \\
Durasi panjang ( $>10$ tahun) & $4(3,5)$ & $115(100,0)$ \\
Jumlah antidiabetes oral & & \\
1 & $73(63,5)$ & \\
2 & $28(24,3)$ & \\
3 & $14(12,2)$ & \\
$\geq 4$ & $0(0,00)$ & \\
\hline
\end{tabular}

Diabetisi yang menggunakan antidiabetes oral umumnya menderita diabetes berdurasi pendek (76,5\%) dan mayoritas diabetisi hanya menggunakan satu (1) jenis antidiabetes oral $(63,5 \%)$. Data dapat dilihat pada tabel 3.

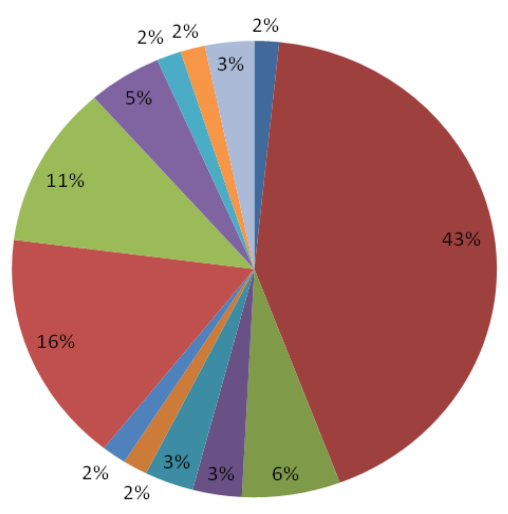

$$
\begin{aligned}
& \text { - Neuropati, nefropati, stroke } \\
& \text { - Neuropati } \\
& \text { - PJK } \\
& \text { - Neuropati dan stroke } \\
& \text { - Neuropati dan retinopati } \\
& \text { - Diabetic Kidney Disease (DKD) dan } \\
& \text { retinopati } \\
& \text { Diabetic Kidney Disease (DKD) dan } \\
& \text { gagal jantung kongestif } \\
& \text { - Retinopati } \\
& \text { - Diabetic Kidney Disease (DKD) } \\
& \text { - Diabetic Kidney Disease (DKD) dan } \\
& \text { neuropati } \\
& \text { - Diabetic Kidney Disease (DKD), gagal } \\
& \text { jantung kongestif, dan neuropati }
\end{aligned}
$$

Gambar 1 Komplikasi Pasien Diabetes Melitus Tipe 2 yang Menggunakan Antidiabetes Oral di Bagian Penyakit Dalam RSUD Kota Bandung Tahun 2017

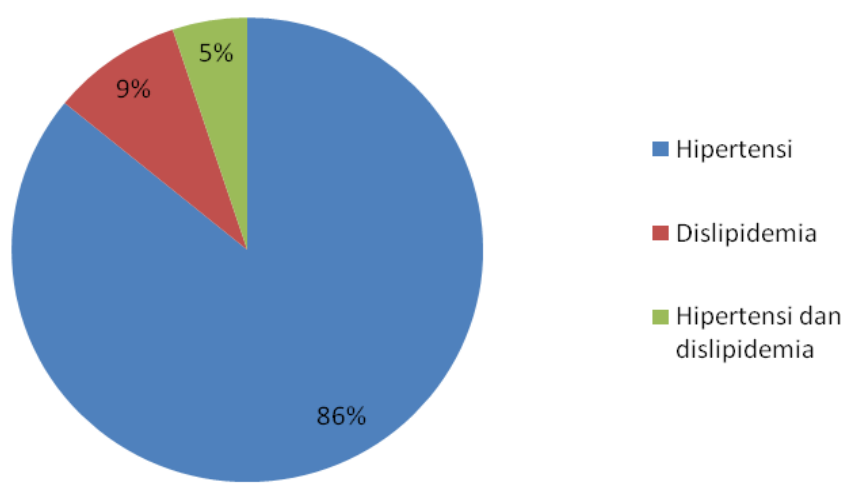

Gambar 2 Komorbid Pasien Diabetes Melitus Tipe 2 yang Menggunakan Antidiabetes Oral di Bagian Penyakit Dalam RSUD Kota Bandung Tahun 2017 
Diabetisi yang menggunakan antidiabetes oral umumnya memiliki komplikasi kronik berupa neuropati (42,6\%) (gambar 1) dan komorbid berupa hipertensi (85,9\%) (gambar 2).

Pada tabel 1 dan 2 terdapat perbedaan jumlah n (\% per total). Hal tersebut disebabkan karena data-data yang bersangkutan tidak tercatat secara lengkap di dalam 115 rekam medis pasien, sehingga penulis mempersentasikan nilai hanya berdasarkan data yang tersedia di dalam rekam medis.

\section{Diskusi}

Diabetisi yang menggunakan antidiabetes oral umumnya berjenis kelamin perempuan. Hasil ini sesuai dengan penelitian di Jerman yang menyatakan bahwa prevalensi diabetes melitus pada perempuan yang berusia 18 - 79 tahun lebih tinggi (5,6\%) dibandingkan dengan laki-laki $(4,7 \%) .{ }^{10}$ Sejalan dengan Laporan hasil Riset Kesehatan Dasar (RISKESDAS) 2018, prevalensi diabetes melitus di Indonesia cenderung lebih tinggi pada perempuan daripada laki-laki. ${ }^{6}$ Kecenderungan tersebut terjadi karena prevalensi sindrom metabolik atau disebut juga sindrom resisten terhadap insulin meningkat pada saat pasca menopause. ${ }^{11}$ Keadaan pasca menopause tersebut dapat membuat distribusi lemak tubuh menjadi lebih mudah terakumulasi, sehingga adiponektin yang bersirkulasi semakin berkurang. Adiponektin yang semakin berkurang dapat meningkatkan risiko terjadinya hiperinsulinemia dan aterogenesis, sehingga dengan keadaan tersebut, penggunaan antidiabetes oral semakin meningkat.. ${ }^{12}$

Diabetisi yang menggunakan antidiabetes oral paling banyak ditemukan pada kelompok usia $\geq 65$ tahun. California Healthcare Foundation / American Geriatric Society (AGS) menemukan bahwa prevalensi diabetes melitus terus meningkat seiring bertambahnya usia, terutama banyak ditemukan pada kelompok usia 65 tahun ke atas. ${ }^{13}$ Titik utama prevalensi diabetes melitus diawali pada usia 45 tahun dan berpuncak pada usia 65 tahun, namun pada usia 75 tahun keatas prevalensi diabetes melitus mulai menurun. ${ }^{14}$ Sejalan dengan American Diabetes Association, faktor yang paling besar asosiasinya terhadap terjadinya diabetes melitus adalah faktor umur, obesitas, dan kurangnya aktivitas fisik. ${ }^{9}$

Prevalensi diabetes melitus mengalami peningkatan sesuai usia, terutama pada yang berusia 45 tahun ke atas. Hal tersebut disebabkan karena pada dekade ketiga dan keempat kehidupan, metabolisme glukosa dalam tubuh mulai terganggu, yaitu sekresi insulin dan respons tubuh terhadap insulin semakin berkurang, pengambilan dan reduksi glukosa hepar terganggu, dan produksi glukosa pada hepar yang semakin meningkat. ${ }^{15}$ Berdasarkan penelitian di Amerika, pada penduduk yang berusia di atas 65 tahun, 20\% diantaranya menderita diabetes melitus tipe 2 . 
Hal tersebut terjadi karena terdapat tiga faktor risiko utama yang berperan, diantaranya adalah gaya hidup sedentair, pola makan yang buruk, dan perubahan komposisi tubuh. ${ }^{16}$

Menurut Centers for Disease Control and Prevention, individu yang berusia lanjut lebih berisikomengalami diabetes melitus tipe 2, karena terjadi resistensi insulin dan fungsi pankreas yang semakin menurun. Resistensi insulin ini disebabkan karena adiposit, sarkopenia, dan kurangnya aktivitas fisik. ${ }^{17}$ Penderita diabetes melitus yang berusia lanjut memiliki tingkat kecenderungan lebih tinggi untuk menderita penyakit lainnya, seperti hipertensi, penyakit jantung koroner, stroke, depresi, gangguan kognitif, gangguan buang air kecil, dan rasa nyeri yang menetap. $^{13}$

Wilayah domisili diabetisi dengan jumlah terbanyak adalah Kotamadya. Hal tersebut sejalan dengan Laporan hasil RISKESDAS 2018 yang menyatakan bahwa prevalensi diabetes melitus yang tinggal di perkotaan lebih tinggi daripada pedesaan. ${ }^{6}$ Penelitian di Amerika menunjukkan bahwa faktor yang berperan dalam terjadinya diabetes melitus tipe 2 adalah faktor genetik, lingkungan, dan faktor metabolik. Faktor lingkungan yang dimaksud adalah westernisasi yang meliputi pola makan yang tinggi kalori dan gaya hidup sedentair. Hal tersebut dapat kita temukan di wilayah perkotaan. ${ }^{14}$

Tingkat pendidikan diabetisi yang menggunakan antidiabetes oral pada penelitian ini umumnya adalah tingkat SMA. Tingkat pendidikan yang lebih tinggi dapat membuat seseorang individu lebih memilki sikap dan pengetahuan yang lebih baik, sehingga kadar glukosa dalam darah lebih mudah terkontrol. Penelitian di Cina menunjukkan bahwa tingkat pendidikan dan pendapatan yang rendah cenderung memiliki kadar glukosa darah yang tinggi. ${ }^{18}$

Diabetisi yang menggunakan antidiabetes oral umumnya tidak bekerja dan didominasi oleh ibu rumah tangga. Sejalan dengan penelitian di Inggris, faktor risiko utama penyebab diabetes melitus tipe 2 adalah faktor genetik dan faktor non-genetik yang dapat dimodifikasi (obesitas dan kurangnya aktivitas fisik). ${ }^{19}$ Kurangnya aktivitas fisik dapat menyebabkan toleransi tubuh terhadap glukosa dan sensitivitas tubuh terhadap insulin semakin berkurang, sehingga hal tersebut dapat menyebabkan orang yang tidak bekerja,seperti ibu rumah tangga, memiliki aktivitas fisik yang kurang dan mengakibatkan tubuhnya kurang sensitif terhadap insulin. ${ }^{20}$

Indeks Massa Tubuh diabetisi pada penelitian ini umumnya memiliki status berat badan normal. Menurut penelitian di Inggris, terdapat perbedaan indeks massa tubuh antara penderita diabetes melitus tipe 2 yang berusia muda dan usia lanjut, yaitu pada penderita diabetes yang berusia muda indeks massa tubuhnya cenderung obesitas, sedangkan pada penderita usia lanjut tidak. ${ }^{16}$ Hal tersebut terjadi karena semakin bertambahnya usia, maka masa tubuh semakin 
berkurang dan persentase adiposit semakin meningkat. Hal ini disebabkan karena dengan adanya pertambahan usia, maka tubuh semakin resisten terhadap insulin, sehingga pengambilan atau pengangkutan glukosa ke dalam otot juga semakin berkurang, dan hal tersebut menyebabkan masa tubuh berkurang. ${ }^{15}$ Menurut penelitian di India, terdapat faktor "Asian Indian Phenotype", yaitu penderita diabetes melitus yang berada di kawasan Asia memiliki lingkar pinggang yang besar, namun indeks massa tubuhnya rendah. ${ }^{21}$

Kontrol glikemik pada penderita diabetes melitus merupakan dasar utama untuk mengurangi risiko morbiditas dan mortalitas, sehingga dengan kontrol glikemik yang terkendali, maka risiko untuk terkena komplikasi makrovaskular dan mikrovaskular dapat berkurang. Kontrol glikemik dapat dinilai dari kadar glukosa darah puasa, glukosa darah 2 jam postprandial, dan HbA1c. HbA1c merupakan gold standard untuk menilai kontrol glikemik, karena konsentrasi $\mathrm{HbA1c}$ dapat menggambarkan nilai rata-rata glikemik dalam $2-3$ bulan terakhir dan dapat memprediksi komplikasi diabetes yang akan terjadi.

Pada penelitian ini, hanya terdapat 2 dari 115 pasien yang diperiksa kadar HbA1c. Sedikitnya data HbAlc yang tersedia pada rekam medis dapat disebabkan karena faktor biaya pemeriksaan yang tinggi atau tidak tersedianya alat pemeriksaan. Hasil penelitian di Ethiopia menunjukan bahwa terdapat korelasi antara glukosa darah 2 jam postprandial dengan $\mathrm{HbA} 1 \mathrm{c}$ dan penelitian tersebut juga menyatakan bahwa sensitivitas, spesifisitas, dan nilai prediksi positif glukosa darah 2 jam postprandial lebih baik daripada glukosa darah puasa, sehingga pada kondisi tidak tersedianya data mengenai HbA1c, maka kadar glukosa darah 2 jam postprandial dapat digunakan dalam memprediksi nilai HbA1c secara akurat. ${ }^{22}$

Diabetisi yang menggunakan antidiabetes oral di RSUD Kota Bandung umumnya sudah dapat mencapai target normal glukosa darah puasa, yaitu sebanyak 50,4\%. Menurut Joslin Diabetes Center's Guidelines for Pharmacological Management of Type 2 Diabetes, nilai normal glukosa darah puasa pada pasien penderita diabetes melitus tipe 2 adalah $70-130 \mathrm{mg} / \mathrm{dl}$. Berbeda dengan nilai normal glukosa darah puasa bagi individu yang tidak menderita diabetes yaitu 70 $99 \mathrm{mg} / \mathrm{dl}$.Menurut penelitian Ambady et al, antidiabetes oral seperti metformin dan sulfonylurea lebih dapat menurunkan kadar glukosa darah puasa daripada kadar glukosa darah lainnya. ${ }^{23}$

\section{Joslin Diabetes Center's Guidelinesfor Pharmacological Management of Type 2} Diabetes menjelaskan bahwa nilai normal glukosa darah $2 \mathrm{hPP}$ pada penderita diabetes melitus tipe 2 adalah $<180 \mathrm{mg} / \mathrm{dl}$. Hal tersebut berbeda dengan mereka yang tidak menderita diabetes, yaitu $<140 \mathrm{mg} / \mathrm{dl}$. Batasan nilai normal untuk glukosa darah penderita diabetes melitus tipe 2 lebih tinggi dari orang normal adalah untuk mencegah terjadinya komplikasi akut seperti 
hipoglikemia. ${ }^{24}$ Diabetisi pada penelitian ini umumnya belum dapat mencapai target kendali glukosa darah $2 \mathrm{hPP}$, hal tersebut sejalan dengan penelitian di Inggris yang menyatakan bahwa hiperglikemia postprandial memang merupakan karakteristik utama pada penderita diabetes melitus tipe 2 yang berusia lanjut. ${ }^{17}$ Kondisi tingginya kadar glukosa darah pada pasien diabetes melitus tipe 2 ini terjadi disebabkan oleh faktor obesitas dan gaya hidup sedentair, sehingga hal tersebut menyebabkan diabetes menjadi masalah kesehatan utama. ${ }^{25}$

Sejalan dengan penelitian yang dilakukan oleh Ralph, bahwa dengan adanya pertambahan umur, maka tubuh semakin toleran terhadap glukosa serta absorbsi glukosa oleh hepar dan metabolisme glukosa di perifer juga mulai terganggu. Keadaan tersebut menyebabkan pankreas pada orang yang lanjut usia lebih banyak terpapar glukosa darah, sehingga terjadilah hiperglikemia. ${ }^{15}$ Menurut penelitian di Inggris, kadar glukosa darah yang tinggi dan durasi menderita diabetes yang sudah berlangsung lama dapat menyebabkan prevalensi terjadinya komplikasi dini semakin meningkat. Disimpulkan bahwa pengendalian glosa darah pada penderita DM penting sekali. ${ }^{26}$

Menurut hasil penelitian United Arab Emirates, target terkanan darah pada penderita diabetes melitus yang merupakan keturunan Asia adalah 130/80 mmHg. ${ }^{27}$ Berdasarkan target tersebut, tekanan darah pada diabetisi yang menggunakan antidiabetes oral ini umumnya termasuk dalam kategori non target. Hal tersebut berkaitan dengan adanya gangguan keseimbangan ion magnesium. Hormon insulin berperan penting dalam meredistribusikan magnesium dari ekstraseluler ke intraseluler. Dengan adanya pertambahan usia, respons tubuh terhadap insulin semakin berkurang dan hal tersebut menyebabkan keseimbangan ion magnesium terganggu. Selain itu, masyarakat yang tinggal di wilayah perkotaan cenderung mengonsumsi makanan yang berkalori tinggi dan bermagnesium rendah, sehingga kadar magnesium di dalam tubuh semakin berkurang. Keadaan berkurangnya ion magnesium erat kaitannya dengan meningkatnya prevalensi hipertensi. Hal tersebut terjadi karena magnesium berperan dalam memodulasi tonus dan kontraktilitas otot pembuluh darah, sehingga jika magnesium ekstraseluler semakin rendah, maka kontraktilitas semakin meningkat dan menyebabkan terganggunya homeostasis pembuluh darah, sehingga terjadilah hipertensi. ${ }^{28}$

Kadar kolesterol total, kolesterol HDL, dan kolesterol LDL pada diabetisi umumnya tidak mencapai target. Hal tersebut sejalan dengan penelitian yang dilakukan oleh Framingham Heart Study dan UK Prospective Diabetes Study (UKPDS) yang menyebutkan bahwa wanita yang menderita diabetes melitus memiliki kadar total plasma kolesterol tinggi, kolesterol LDL tinggi, dan kadar plasma kolesterol HDL dua kali lebih rendah daripada wanita yang tidak menderita 


\section{Research Article}

diabetes melitus. Kadar kolesterol total dan kolesterol LDL yang tinggi dan kolesterol HDL yang rendah ini termasuk dalam kategori non target, dan keadaan ini disebut diabetes dislipidemia.

Patogenesis utama diabetes adalah terjadinya resistensi terhadap insulin. Sel lemak yang resisten terhadap insulin ini dapat menyebabkan kadar asam lemak bebas semakin meningkat dan dengan bantuan glikogen, asam lemak bebas tersebut dapat masuk ke dalam hepar dan memfasilitasi produksi trigliserida. Trigliserida yang diproduksi menstimulasi sekresi apolipoprotein B (apoB) dan kolesterol VLDL. Kadar kolesterol VLDL yang semakin meningkat dapat menyebabkan plasma trigliserida meningkat dan kadar kolesterol HDL menurun pada penderita diabetes melitus. ${ }^{29}$ Fraksi lipoprotein yang abnormal dengan durasi menderita diabetes melitus yang sudah berlangsung lama dapat menyebabkan terjadinya komplikasi, salah satunya adalah Diabetic Kidney Disease (DKD). Oleh karena itu kadar kolesterol pasien harus tetap dipantau agar terjadinya komplikasi dini dapat dicegah.

Kadar kreatinin umumnya termasuk normal atau mencapai target, yaitu $<1,4 \mathrm{mg} / \mathrm{dl}$ pada pria dan $<1,2 \mathrm{mg} / \mathrm{dl}$ pada perempuan. Hal ini sejalan dengan penelitian yang dilakukan oleh Huxley, yaitu pada nilai IMT yang sama, orang Asia cenderung memiliki massa total otot skeletal yang lebih rendah daripada orang Kaukasia. Otot skeletal merupakan target utama insulin, sehingga ketika terjadi resistensi insulin, target otot skeletal tersebut semakin berkurang. Kadar kreatinin secara langsung dapat merefleksikan massa otot skeletal, sehingga hal tersebut menyebabkan penderita diabetes melitus tipe 2 terutama pada orang Asia cenderung memiliki kadar kreatinin yang lebih rendah atau pada penelitian ini termasuk kategori normal/mencapai target. ${ }^{30}$

Diabetisi yang menggunakan antidiabetes oral umumnya menderita diabetes berdurasi pendek, yaitu $<5$ tahun. Hal tersebut disebabkan karena diabetes melitus tipe 2 merupakan suatu penyakit kompleks dan progresif yang sulit disembuhkan secara efektif untuk jangka waktu yang lama. ${ }^{31}$ Sejalan dengan American Diabetes Association, diabetes merupakan suatu penyakit kronik yang membutuhkan pengobatan jangka panjang untuk mencegah terjadinya komplikasi akut maupun kronik. Pengobatan diabetes melitus tipe 2 tidak hanya memerlukan antidiabetes oral, tetapi juga melibatkan perubahan gaya hidup dan bahkan penggunaan insulin untuk menjaga agar kadar glukosa darah tetap terkontrol. ${ }^{32}$ Penggunaan antidiabetes oral tunggal bermula ketika intervensi gaya hidup, pola makan, dan olah raga sudah tidak mampu lagi untuk menjaga HbA1C $<7 \%$. Glukosa darah yang tidak dapat lagi terkontrol dalam waktu yang cukup lama dapat menyebabkan risiko untuk terkena komplikasi mikro dan makrovaskular dan hal tersebut mengakibatkan pasien akan diberikan terapi selanjutnya, yaitu berupa inisiasi insulin. ${ }^{33}$ 
Penelitian yang dilakukan di Inggris menunjukkan sebanyak 9\% penderita diabetes melitus tipe 2 yang menderita komplikasi mikrovaskular terjadi dalam durasi 9 tahun setelah didiagnosis diabetes. Penggunaan insulin umumnya dilakukan pada durasi sedang yaitu dalam kurun waktu 6 - 10 tahun setelah didiagnosis menderita diabetes melitus tipe $2 .{ }^{26}$ Berdasarkan kriteria eksklusi pada penelitian ini, pasien diabetes melitus tipe 2 yang hanya menggunakan antidiabetes oral cenderung termasuk dalam durasi pendek, yaitu $<5$ tahun. Hal tersebut disebabkan karena setelah 3 tahun menderita diabetes, hanya sekitar 50\% penderita diabetes melitus tipe 2 yang menggunakan obat antidiabetes oral tunggal yang kontrol glikemiknya baik. ${ }^{34}$

Antidiabetes oral yang diberikan umumnya merupakan antidiabetes oral tunggal (monoterapi). Hal ini sesuai dengan American Diabetes Association (ADA) dan European Association for the Study of Diabetes (EASD) yang menyebutkan bahwa metformin merupakan antidiabetes oral tunggal lini pertama yang digunakan sebagai terapi farmakologis pada penderita diabetes melitus tipe 2. Hal tersebut disebabkan karena efek yang dihasilkan oleh metformin tidak berisiko terhadap peningkatan berat badan dan tidak menyebabkan hipoglikemia. ${ }^{35}$

Komplikasi pada diabetisi yang menggunakan antidiabetes oral umumnya adalah neuropati. Menurut penelitian Mooradian et al, penderita diabetes yang berusia lanjut lebih rentan terkena komplikasi diabetes. Hal tersebut disebabkan karena mekanisme pertahanan untuk melawan glukotoksisitas mulai berkurang seiring dengan pertambahan usia, sehingga menyebabkan kondisi hiperglikemia yang tidak terkontrol. ${ }^{16}$

Hiperglikemia postprandial dapat menyebabkan aterosklerosis melalui mekanisme aktivasi koagulasi darah dan stres oksidatif, sehingga kondisi hiperglikemia tersebut dapat menyebabkan toksisitas pada serabut saraf, terutama serabut saraf kecil. Hal tersebut sejalan dengan penelitian ini, yaitu dengan tingginya prevalensi penderita diabetes yang berusia $\geq 65$ tahun, maka komplikasi yang umumnya terjadi pada penderita berusia lanjut adalah neuropati. ${ }^{36}$ Komorbid utama yang umumnya terjadi adalah hipertensi. Hal tersebut sejalan dengan penelitian yang menyatakan bahwa $75 \%$ penderita diabetes melitus tipe 2 memiliki komorbiditas hipertensi. ${ }^{36}$

Pasien diabetes melitus tipe 2 yang menggunakan antidiabetes oral di RSUD Kota Bandung pada tahun 2017 masih banyak yang kadar glukosa darahnya belum mencapai target, yaitu sebanyak 51,3\% dan angka kejadian komplikasi serta komorbid diabetes pada diabetisi yang menggunakan antidiabetes oral juga tinggi, yaitu sebanyak 63,9\%. Hal tersebut menunjukkan bahwa sangat diperlukannya kerja sama yang baik antara pihak pasien, tenaga medis, dan penyedia fasilitas pelayanan kesehatan, terutama dalam bidang edukasi, konseling, monitoring, 
manajemen diri, dan terapi farmakologis, sehingga dengan nilai glikemik yang terkendali, angka kejadian komplikasi dini dan komorbid diabetes diharapkan semakin berkurang.

Keterbatasan pada penelitian ini yaitu tidak semua data pasien tercatat dalam rekam medis secara lengkap dan jelas, waktu penelitian terbatas, pemeriksaan laboratorium yang tidak rutin dilakukan, dan pasien yang tidak dapat hadir pada saat pemeriksaan. Keterbatasan penelitian tersebut menyebabkan terdapat beberapa variabel yang tidak dapat memenuhi jumlah data sesuai yang dibutuhkan untuk penelitian ini, yaitu sebanyak 115 data.

\section{Simpulan}

Pasien umumnya berjenis kelamin perempuan (67,8\%), kelompok umur $\geq 65$ tahun (40,0\%), bertempat tinggal di perkotaan $(87,6 \%)$, lulusan SMA $(35,2 \%)$, dan tidak bekerja $(63,6 \%)$. Pasien umumnya memiliki IMT normal $(45,9 \%)$ dan memiliki beberapa variabel yang mencapai target, yaitu glukosa darah puasa $(50,4 \%)$, trigliserida $(55,3 \%)$, dan kreatinin $(69,6 \%)$. Pasien juga memiliki beberapa variabel yang tidak mencapai target, diantaranya adalah glukosa darah 2 jam postprandial (51,3\%), tekanan darah (65,8\%), kolesterol total $(55,6 \%)$, kolesterol HDL (54,5\%), kolesterol LDL (80,0\%), dan ureum (56,0\%). Pasien yang menggunakan antidiabetes oral umunya berdurasi $<5$ tahun $(76,3 \%)$ dan menggunakan monoterapi $(63,5 \%)$. Neuropati $(42,6 \%)$ dan hipertensi $(85,9 \%)$. Saran dari penelitian ini adalah menjadikan dasar pemikiran bahwa pemeriksaan laboratorium seperti kolesterol ( HDL dan LDL) dan HbA1c yang merupakan gold standard evaluasi pengobatan penderita DM, dapat disertakan sebagai pelayanan yang termasuk dalam lingkup pembayaran kapitasil.

\section{Daftar Pustaka}

1. David G. Gardner, MD M, Shoback D. Greenspan's Basic \& Clinical Endocrinology, Ninth Edition. China: Mc Graw Hill; 2011. 587 p.

2. Soelistijo SA, Novida H, Rudijanto A, Soewanda P, Suastika K, Manaf A, et al. Konsensus Pengolahan dan Pencegahan Diabetes Melitus Tipe 2 Di Indonesia 2015. Pengurus Besar Perkumpulan Endokrinologi Indonesia (PB PERKENI); 2015.

3. World Health Organization. Global Report on Diabetes. 2016;

4. IDF. IDF Diabetes Atlas. International Diabetes Federation. 2015. 1-163 p.

5. Cockram CS. The epidemiology of diabetes mellitus in the Asia-. 2000;6(1):43.

6. Kesehatan K. HASIL UTAMA RISKESDAS 2018. 2018;67-78.

7. Tunceli K, Bradley CJ, Nerenz D, Williams LK, Pladevall M, Lafata JE. The impact of diabetes on employment and work productivity. Diabetes Care. 2005;28(11):2662-7.

8. Economic Costs of Diabetes in the U.S. in 2012. 2012;36:1033.

9. American Diabetes Association. Diagnosis and Classification of Diabetes Mellitus. Diabetes Care. 2014;37(January):81-90

10. Christa Meisinger, MD, MPH; Barbara Thorand, PhD, MPH; Andrea Schneider; Jutta Stieber, MD; Angela Do ring, MD; Hannelore Lo“wel M, Objective: Sex Differences in Risk Factors for Incident Type 2 Diabetes Mellitus. archinternmed. 2002;162:82-9.

11. Salpeter SR, Walsh JME, Ormiston TM, Greyber E, Buckley NS, Salpeter EE. Meta-analysis : effect of hormonereplacement therapy on components of the metabolic syndrome in postmenopausal women. Diabetes, Obes Metab. 
2006;8:538-54.

12. Cnop M, Havel PJ, Utzschneider KM, Carr DB, Sinha MK, Boyko EJ, et al. Relationship of adiponectin to body fat distribution, insulin sensitivity and plasma lipoproteins: evidence for independent roles of age and sex. Diabetologia. 2003;46:459-69.

13. Goal- IOFI, In S, Mellitus D. Guidelines for Improving the Care of the Older Person with Diabetes Mellitus California Healthcare Foundation/American Geriatrics Society Panel on Improving Care for Elders with Diabetes. Am Geriatr Soc. 2003;51:s265-80.

14. Fletcher B, Gulanick M, Lamendola C. Risk factors for type 2 diabetes mellitus. J Cardiovasc Nurs. 2002;16(2):1723.

15. Ralph A. Glucose Intolerance and Aging. Diabetes Care. 1981;4(4):493-501.

16. Mooradian AD, McLaughlin S, Boyer CC. Diabetes Care for Older Adults. Diabetes Care.1999;12:2650-64.

17. Affairs M, Information C, Physicians E, Arbor A, Israel B, Medical D. Diabetes in Older Adults. Diabetes Care. 2012;35(10):2650-64.

18. Monnier L, Colette CP. Target for Glycemic Control. Diabetes Care. 2009;32(2):s199-204.

19. England TN. Prevention Of Type 2 Diabetes Mellitus By Changes In Lifestyle Among Subject With Impaired Glucose Tolerance. N Engl J Med. 2001;344(18):1343-50.

20. Natural R, Proctitis GH, Williams A, Kreel I. Physical activity and incidence of non-insulin-dependent diabetes mellitus in women. Lancet. 1991;338:774-8.

21. V. Mohan, Sandeep S, Deepa R. Epidemiology of type 2 diabetes: Indian scenario. 2007. p. 217-30.

22. Ketema EB, Kibret KT. Correlation of fasting and postprandial plasma glucose with HbA1c in assessing glycemic control; systematic review and. Arch Public Heal [Internet]. 2015;73:43:1-9. Available from: http://dx.doi.org/10.1186/s13690-015-0088-6

23. Ambady Ramachamdran M, Matthew C. Riddle M, Conrad Kabali Ph. Relationship Between A1C and Fasting Plasma Glucose in Dysglycemia or Type 2 Diabetes. Diabetes Care. 2012;35:749-53.

24. Vlckova V, Cornelius V, Kasliwal R, Wilton L, Shakir SAW. Hypoglycaemia with Oral Antidiabetic Drugs Results from Prescription-Event Monitoring Cohorts of Rosiglitazone, Pioglitazone, Nateglinide and Repaglinide. drug Saf. 2009;32(5):409-18.

25. Third T, Health N, Survey NE. Prevalence of Diabetes, Impaired Fasting Glucose, and Impaired Glucose Tolerance in U.S. Adults. Diabetes Care. 1998;21(4):518-24.

26. Prospective UK, Study D. Intensive blood-glucose control with sulphonylureas or insulin compared with conventional treatment and risk of complications in patients with type 2 diabetes ( UKPDS 33 ). Lancet. 1998;352(Ukpds 33):837-53.

27. Jelinek HF, Osman WM, Khandoker AH, Khalaf K, Lee S, Almahmeed W, et al. Clinical profiles , comorbidities and complications of type 2 diabetes mellitus in patients from United Arab Emirates. BMJ. 2017;5(427):1-10.

28. Paolisso G, Barbagallo M. Hypertension, Diabetes Mellitus, and Insulin Resistance. Am J Hypertens. 1997;7061:346-55.

29. Mooradian AD. Dyslipidemia in type 2 diabetes mellitus. Nat Clin Pract Endocrinol Metab. 2009;5(3):150-9.

30. Kansai T, Study H. Lower Serum Creatinine Is a New Risk Factor of Type 2 Diabetes. Diabetes Care. 2009;32(3):424-6.

31. Krentz AJ, Bailey CJ. Oral Antidiabetic Agents Current Role in Type 2 Diabetes Mellitus. Drugs. 2005;65(3):385411.

32. Diabetes VII, In C. Standards of Medical Care in Diabetes - 2011. Diabetes Care. 2011;34.

33. Korytkowski M. When oral agents fail : practical barriers to starting insulin. Int J Obes. 2002;18-24.

34. Oral Antihyperglycemic Therapy for Type 2 Diabetes. JAMA. 2002;287(3):360-72.

35. Inzucchi SE, Bergenstal RM, Buse JB, Diamant M, Ferrannini E, Nauck M, et al. Management of hyperglycaemia in type 2 diabetes: A patient-centered approach. Position statement of the american diabetes association (ADA) and the european association for the study of diabetes (EASD). Diabetologia. 2012;55(6):1577-96.

36. Statements P. Post Prandial Blood Glucose. Diabetes Care. 2001;24(4):775-8. 